\title{
SISTEM INFORMASI PENYALURAN BANTUAN PUPUK BERSUBSIDI PADA DINAS PERTANIAN DAN PANGAN KABUPATEN REMBANG BERBASIS WEB
}

\author{
Ida Siti Marfuah ${ }^{1}$, Yudie Irawan ${ }^{2}$ \\ ${ }_{1,2}$ Program Studi Sistem Informasi, Fakultas Teknik, Universitas Muria Kudus
}

\section{Article Info:}

Dikirim: 09 Juni 2021

Direvisi: 17 Juni 2021

Diterima: 29 Juni 2021

Tersedia Online: 30 Juni 2021

Penulis Korespondensi:

Ida Siti Marfuah

Universitas Muria Kudus, Kudus, Indonesia

Email:201753095@std.umk.ac.id

\begin{abstract}
Abstrak: Pemberian bantuan pupuk bersubsidi telah menjadi program pemerintah sejak tahun 2003 yang berlaku secara nasional. Namun dibeberapa daerah pelaksanaannya masih mengalami banyak kendala, seperti halnya yang terjadi di wilayah Kabupaten Rembang. Dinas Pertanian dan Pangan Kabupaten Rembang telah memanfaatkan komputer sebagai alat bantu untuk mengelola proses pendistribusian pupuk bersubsidi mulai dari penyediaan, pengawasan dan proses penyalurannya. Namun prosesnya masih dirasa menemui banyak kendala baik dari pihak petani maupun pihak petugas, karena sebagian besar kegiatannya masih dicatat dalam buku dan kertas. Sedangkan aplikasi Ms. Excel digunakan hanya sebatas pendataan petani tanpa konsep manajemen database yang baik yang pada akhirnya menyulitkan petugas saat melakukan pemeriksaan, pencarian dan dalam pembuatan laporan. Proses ini mengakibatkan pencatatan berulang data yang sama dan berpotensi tidak akurat lagi sehingga tidak dapat dijadikan dasar untuk pengambilan keputusan oleh pimpinan. Penelitian ini menawarkan solusi dengan cara pengembangan sistem informasi yang diharapkan mampu meningkatkan mengelola proses penyaluran pupuk bersubsidi. Metode pengembangan sistem mengacu pada model Waterfall dengan pendekatan metodologi berorientasi objek. Perangkat perancangan yang digunakan dalam penelitian ini adalah Unified Modelling Language(UML). Hasil dari penelitian ini adalah Sistem Informasi Penyaluran Bantuan Pupuk Bersubsidi Pada Dinas Pertanian dan Pangan Kabupaten Rembang berbasis Web.
\end{abstract}

Kata kunci: sistem informasi; penyaluran; pupuk bersubsidi.

\begin{abstract}
The government has a subsidized fertilizer program since 2003 which applies nationally. However, in some areas the implementation is still experiencing many obstacles, this is what happened in Rembang Regency. The Department of Agriculture and Food of Rembang Regency uses computers as a tool to manage the distribution process of subsidized fertilizers starting from the provision, supervision and distribution process. However, the process encountered many obstacles, both on the part of the farmers and the agency, because most of their activities were recorded in books and paper. While the application of Ms. Excel is used only to collect data on farmers without a good database management concept. On the other hand, it becomes difficult to conduct inspection, search and report generation. This process results in data redundancy and data inconsistency. The data is not suitable for decision making. This research offers a solution by developing an information system that is expected to improve managing the distribution of subsidized fertilizers. The system development method used is the Waterfall model with an object-oriented methodological approach. The design tool used is the Unified Modeling Language (UML). The result of this research is a Web-based Information System for the Distribution of Subsidized Fertilizer Aid at the Department of Agriculture and Food in Rembang Regency.
\end{abstract}

Keywords: information systems; distribution; subsidized fertilizer. 


\section{PENDAHULUAN}

Pada era globalisasi saat ini perkembangan teknologi telah bertransformasi sangat pesat dan mampu memberikan manfaat yang banyak pada berbagai bidang, khususnya pada teknologi informasi. Pengelolaan data dalam rangka untuk kepentingan pengumpulan, pengolahan, penyusunan, penyimpanan dan manipulasi data dengan berbagai metode yang bermuara pada hasil informasi yang berkualitas, memiliki akurasi yang tinggi, relevan dengan objek yang diinginkan dan tepat sesuai dengan kebutuhan user adalah penerapan dari teknologi informasi. Sistem yang terkomputerisasi sekarang telah digunakan diberbagai aspek pekerjaan karena keunggulannya yang mampu menghasilkan informasi dengan tepat serta mempermudah dan mempercepat proses - proses operasional yang dibutuhkan.

Pendapatan per kapita Kabupaten Rembang paling besar didapat dari sektor Pertanian, Kehutanan, dan Perikanan sebagai sektor utama. Dibuktikan dengan adanya laporan PDRB per kapita dari tahun 2013-2016 terus meningkat dari Rp. 18.272,55 ribu sampai Rp. 23.744,16 ribu, dimana untuk sektor Pertanian, Perikanan dan Kehutanan mampu menyumbang rata - rata 29\% sampai $33 \%$ dari tahun 2013 sampai pada tahun 2016. Sehingga menempatkan sektor Pertanian,Perikanan dan Kehutanan sebagai sektor yang memberikan andil paling besar dalam struktur perekonomian daerah Kabupaten Rembang [1]. Namun jika diteliti lebih lanjut maka sumbangan dari sektor ini semakin mengecil dari tahun 2013 sebesar $33 \%$ menjadi hanya $29 \%$ pada tahun 2016.

Salah satu program dari Dinas Pertanian dan Pangan Kabupaten Rembang untuk menjaga ketahanan pangan adalah program pupuk bersubsidi yang berjalan dibawah koordinasi Kementrian Pertanian Republik Indonesia berdasarkan Surat Keputusan Menperindag No. 70/MPP/Kep/2/2003 tertanggal 11 Pebruari 2003, yaitu mengenai Pengadaan dan Penyaluran Pupuk Bersubsidi Untuk Sektor Pertanian.

Kebijakan subsidi pupuk ini diharapkan mampu melindungi petani, meningkatkan produktivitas dan meningkatkan taraf perekonomian para petani. Namun, masalah pupuk di Indonesia sudah lama menjadi persoalan yang berkaitan langsung pada kebutuhan dan keberlangsungan petani dalam mengelola lahan atau sawahnya [2].

Pada penelitian lain yang ada ada kaitannya dengan penelitian ini, adalah yang dilakukan oleh Mayang Sari, membahas tentang Sistem Pengolahan Data Kelompok Tani Kecamatan Sungai Tabuk Kabupaten Banjar menjelaskan bahwa kendala yang sering terjadi pada manajemen pembagian pupuk bersubsidi berkisar pada proses pengelolaan datanya yang semi manual, sehingga masih banyak menghasilkan berkas - berkas. Berkas yang bertumpuk - tumpuk ini menyulitkan bagi pengelola sehingga mengakibatkan keterlambatan pada penyaluran pupuk bersubsidi kepada kelompok tani karena data masih dihitung dengan cara manual. Demikian juga menjadi kendala dalam menyusun laporan, dimana pengelola harus menghitung kembali dengan cara manual antara lain mengenai penebusan pupuk, penyaluran pupuk dan sisa stok pupuk, hal ini membuat penyusunan laporan membutuhkan waktu yang relatif lama [3].

Pada penelitian lainnya yang dilakukan oleh Ni Ketut Sriwinarti dan Andres Faesal tentang Sistem Informasi Distribusi Pupuk Bersubsidi Pada Kecamatan Gerung Lombok Barat menjelaskan bahwa Sistem informasi pendistribusian pupuk di Kecamatan Gerung, telah dirancang dengan harapan agar mampu menjadi solusi atas permasalahan khususnya pada garis akhir yaitu ketidaktepatan dalam distribusi pupuk bersubsidi. Petani yang terdaftar pada kelompok tani dan juga terdaftar pada RDKK(Rencana Definitif Kebutuhan Kelompok Tani) yang lalu digunakan pengecer untuk penebusan pupuk berhak memperoleh kartu identitas. Dengan kartu identitas ini para petani dapat langsung menemui pengecer kemudian pengecer melakukan pengecekan biodata dan kuota pupuk yang dimiliki oleh setiap petani[4].

Kendala yang sama juga dirasakan para pengelola dan petani terkait dengan pendistribusian pupuk bersubsidi yang ada di wilayah Kabupaten Rembang. Dalam pendistribusian dan pengelolaan data penyaluran pupuk bersubsidi masih menggunakan metode semi manual yaitu dengan mencatat luas lahan dan anggota kelompok tani pada buku dan aplikasi Ms. Excel. Pengisian data petani juga sering berubah karena tidak tidak diberikan ketentuan yang jelas saat pencatatan data petani. Karena hal itulah maka pengelola menjadi sulit untuk diminta data - datanya karena banyaknya berkas yang harus dicatat ulang untuk menulis laporan - laporan yang diperlukan.

Berdasarkan penjelasan diatas, maka pada penelitian ini mengangkat judul "Sistem Informasi Penyaluran Bantuan Pupuk Bersubsidi Pada Dinas Pertanian dan Pangan Kabupaten Rembang berbasis Web". Sistem ini diharapkan dapat mempermudah pengelolaan data kelompok tani dalam proses permintaan pupuk bersubsidi sehingga data yang diperoleh dapat dimanfaatkan untuk kebutuhan yang lain, diantaranya pemantauan pendistribusian pupuk supaya tepat sasaran.

\section{METODOLOGI PENELITIAN}

\subsection{Metode Pengumpulan Data}

Metode yang digunakan untuk mendapatkan data yang dapat dipastikan akurat, maka peneliti mencari sumber data dengan metode :

a. Observasi.

Data diperoleh dengan cara pengamatan dan pencatatan dilapangan pada kendala - kendala yang telah dibahas pada objek yang diteliti secara langsung untuk dikumpulkan dan digunakan sebagai bahan penelitian pada Dinas Pertanian dan Pangan Kabupaten Rembang.

b. Wawancara 
Pengumpulan data didapatkan dengan tanya jawab langsung kepada pihak - pihak yang terlibat dalam proses penyaluran pupuk bersubsidi kepada petani, baik pihak dari Dinas Pertanian dan Pangan maupun dari kelompok - kelompok tani.

c. Studi Kepustakaan

Metode studi kepustakaan terkait dengan pengumpulan data - data yang bersifat sekunder yang dikumpulkan secara tidak langsung dan berasal dari buku - buku mengenai perancangan sistem dan pedoman program distribusi pupuk bersubsidi pada petani untuk memperoleh gambaran proses bisnis yang ada.

d. Studi Dokumentasi

Pada metode ini pengumpulan data dilakukan dengan melakukan pengecekan dan menganalisis dokumen - dokumen yang telah dihasilkan oleh petugas yang terkait yang ada hubungan tema penelitian. Misalnya laporan stok pupuk, laporan data petani dan laporan penebusan pupuk.

\subsection{Metode Pengembangan Sistem}

Metode pengembangan sistem yang digunakan sebagai acuan pada penelitian ini adalah Waterfall model. Metode Waterfall atau kadang-kadang disebut classic life cycle, menggunakan pendekatan sistematis dan berurutan(sequential) untuk pembuatan aplikasi yang diawali dengan menganalisis secara spesifik kebutuhan pelanggan dan dikembangkan melalui perencanaan, desain, pembentukan struktur, dan penyebaran, yang pada akhirnya menjadi faktor pendukung yang berkelanjutan dari aplikasi yang berhasil diselesaikan [5]. Tahapan pengembangan sistem yang berdasarkan pada model Waterfall dapat dijelaskan yaitu antara lain :

a. Analisis Kebutuhan

Dalam tahap ini yang dilakukan adalah menganalisis semua kebutuhan user. Dokumen yang dihasilkan pada tahap ini adalah user requirement atau data yang ada kaitannya dengan kebutuhan pengguna dalam pengembangan sistem yang baru. Dokumen tersebut yang akan menjadi referensi dalam pembuatan sistem.

b. Desain Sistem

Dalam tahap ini semua kebutuhan user yang telah diperoleh akan diterjemahkan dalam bentuk perancangan atau desain sistem. Proses desain yang dibuat antara lain struktur data, arsitektur, antar muka dan algoritma. Pada tahapan ini dokumen yang dihasilkan adalah software requirement. Dokumen tersebut akan menjadi acuan bagi programmer dalam menulis kode program.

c. Penulisan Kode Program

Dalam tahap ini kode program dibuat dengan mengacu dari dokumen perancangan yang telah dihasilkan dari tahap desain sistem dengan bahasa pemrograman tertentu yang akan menghasilkan aplikasi/sistem yang dibutuhkan user.

d. Pengujian dan Penerapan Program

Setelah tahap penulisan kode program selesai maka tahap berikutnya adalah melakukan pengujian pada aplikasi yang telah dibangun. Selain menemukan kesalahan secara teknis, pengujian juga bertujuan untuk menjamin bahwa sistem telah dibuat sesuai dengan alur bisnis yang dibutuhkan pengguna.

e. Pemeliharaan

Tahap ini diperlukan untuk memastikan sistem mampu berkembang mengikuti perubahan kebutuhan user. Beberapa perubahan menyangkut dengan lingkungan sistem yang baru, atau memang karena ada perkembangan kebutuhan dari pihak user.

\section{HASIL DAN PEMBAHASAN}

\subsection{Analisis Sistem yang Berjalan}

Permasalahan yang dapat diidentifikasi pada Dinas Pertanian dan Pangan Kabupaten Rembang pada penelitian ini khususnya dalam mengelola data bantuan pupuk bersubsidi kepada petani adalah sebagai berikut :

a. Proses pengumpulan data dari kelompok tani ,data penebusan pupuk dan data - data lainnya menyebabkan penumpukan berkas karena masih menggunakan metode pencatatan manual.

b. Proses pencarian data memerlukan waktu yang relatif cukup lama karena pencariannya dilakukan pada berkas - berkas yang menumpuk.

c. Data permintaan bantuan pupuk bersubsidi berpusat pada penyuluh petani/kelompok tani, sehingga data pada Dinas Pertanian dan Pangan Kabupaten Rembang kurang terupdate pada saat diminta laporan terkini.

d. Proses koreksi jika ada pembetulan permintaan bantuan pada proses verifikasi oleh pemegang program di TPP harus menghubungi pengelola program penyuluh untuk melakukan pembetulan data. 


\subsubsection{FOD (Flow of Document)}

Bagan alir dokumen (Flow of Document) atau disebut juga bagan alir formulir atau paperwork flowchart adalah bagan alir yang menunjukkan aliran dari laporan - laporan dan formulir serta tembusannya. Bagan alir dokumen ini memanfaatkan simbol - simbol yang serupa dengan simbol - simbol pada bagan alir sistem [6].

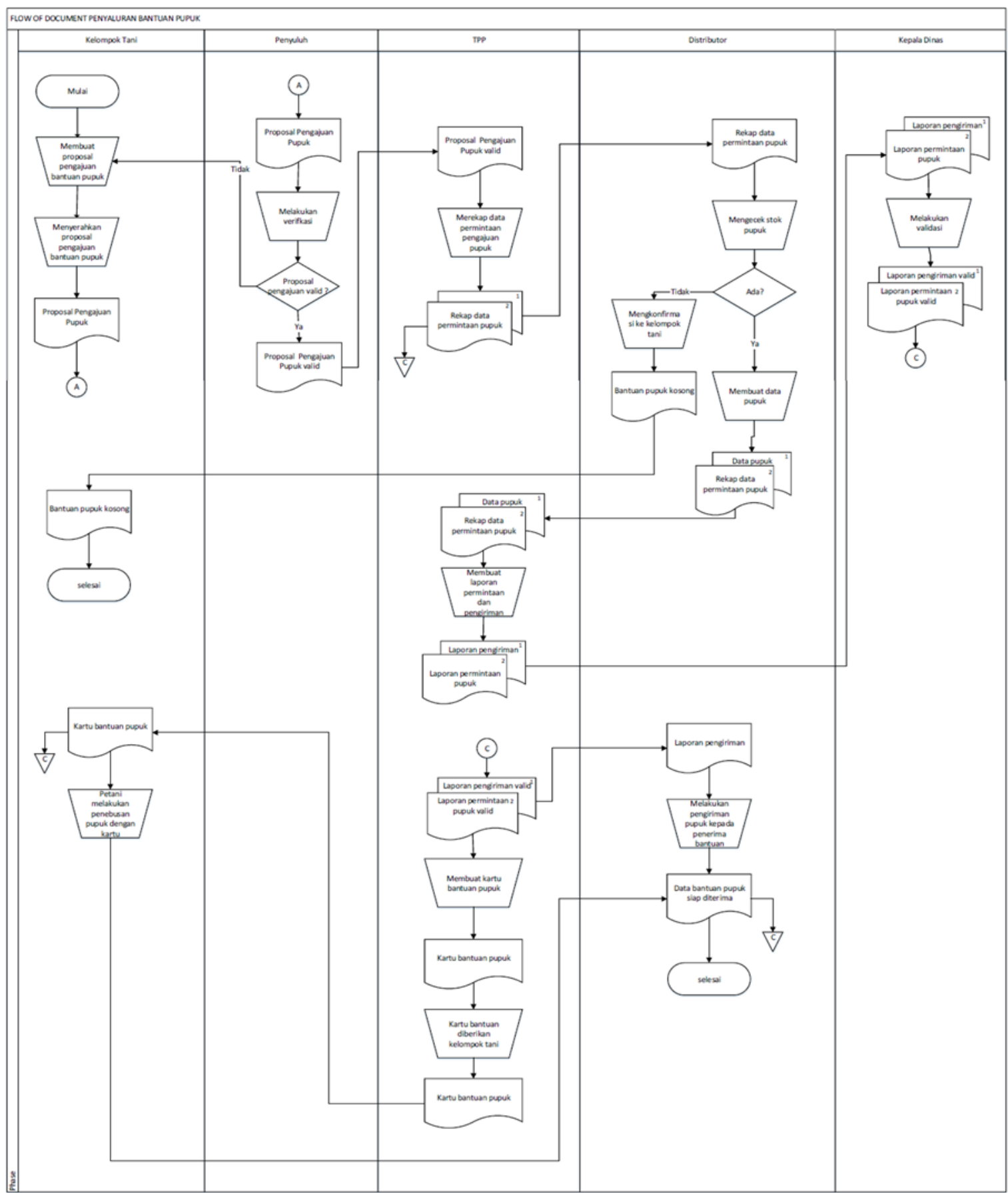

\section{Gambar 1. Flow of Document Penyaluran Bantuan Pupuk}

Metode manual yang dijalankan pada proses distribusi pupuk bersubsidi dapat dilihat pada gambar 1, dimana terlihat data - data yang terpisah karena sistem pencatatan manual pada kertas dan buku.

\subsection{Analisis dan Perancangan Sistem Baru}

Perancangan sistem pada penelitian ini adalah pendekatan metodologi berorientasi objek. Perangkat pemodelan pada penelitian ini adalah Unified Modelling Language(UML). UML merupakan standar industri dalam pemodelan sistem berorientasi objek. Perangkat UML terdiri atas diagram - diagram yang memungkinkan perancang menggambarkan struktur sistem berorientasi objek. Setiap iterasi desain menyajikan 
tampilan yang semakin detail berurutan pada desain sistem sehingga semua hal dan relasi pada sistem mampu didefinisikan dengan sangat jelas dan tepat [7].

\subsubsection{Business Use Case}

Business use case diagram adalah perangkat untuk mengenali dan memvisualisasikan seluruh proses bisnis yang ada didalam sistem. Dari analisis pelaku bisnis yang telah dilakukan, dihasilkan gambaran aktivitas bisnis pada sistem yang dapat dilihat pada gambar 2. Pada diagram tersebut terdapat 3(tiga) Business Worker dan 2(dua) Business Actor.

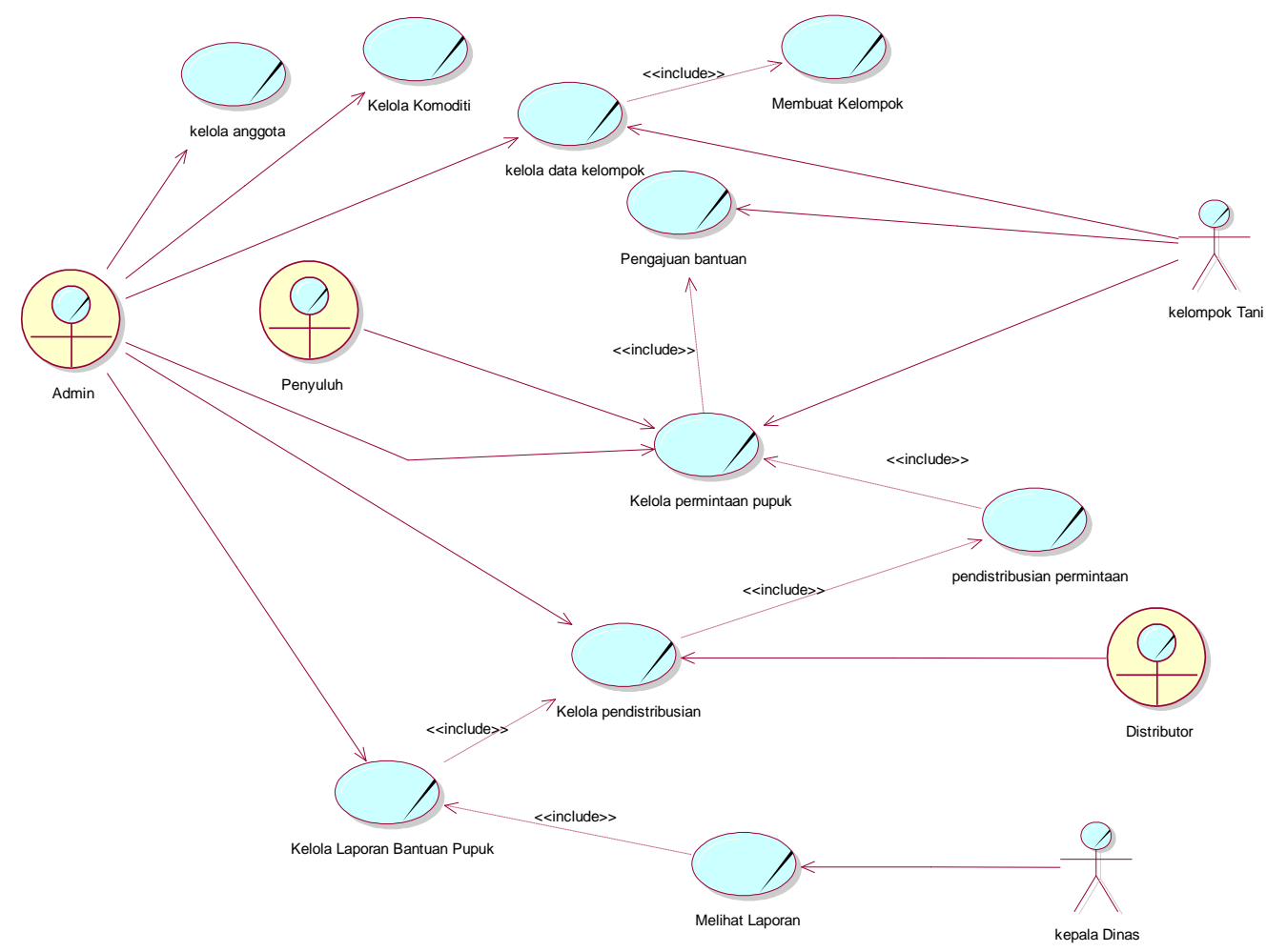

Gambar 2. Business Use Case Diagram Sistem Informasi Penyaluran Bantuan Pupuk Bersubsidi

\subsubsection{System Use Case}

System Use Case menggambarkan interaksi user dengan sistem. Pada system use case dari Sistem Informasi Penyaluran Bantuan Pupuk Bersubsidi Pada Dinas Pertanian dan Pangan Kabupaten Rembang berbasis Web dapat dilihat pada gambar 3. Pada system use case tersebut terdapat 10(sepuluh) proses atau use case yang prosesnya dilakukan oleh para aktor yaitu Admin, Penyuluh, Kelompok Tani, Distributor dan Kepala Dinas.

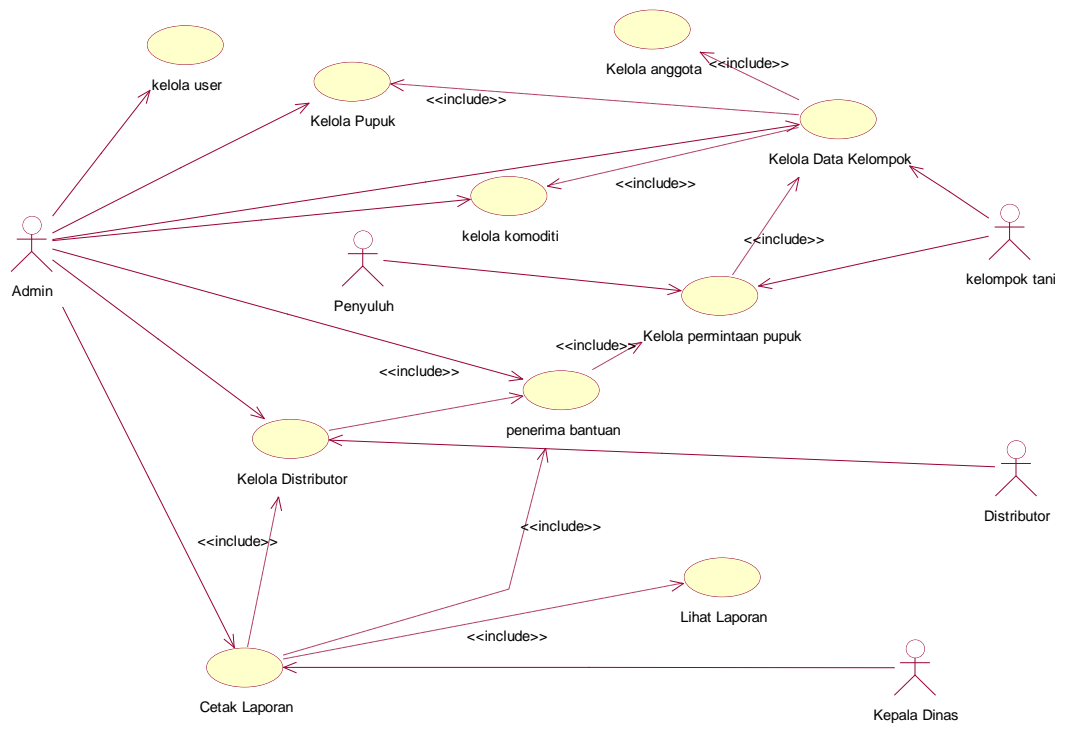

Gambar 3. System Use Case Diagram Sistem Informasi Penyaluran Bantuan Pupuk Bersubsidi 


\subsubsection{Class Diagram}

Class Diagram dari Sistem Informasi Penyaluran Bantuan Pupuk Bersubsidi dapat dilihat pada gambar 4. Class Diagram menggambarkan interaksi antar class dalam sistem.

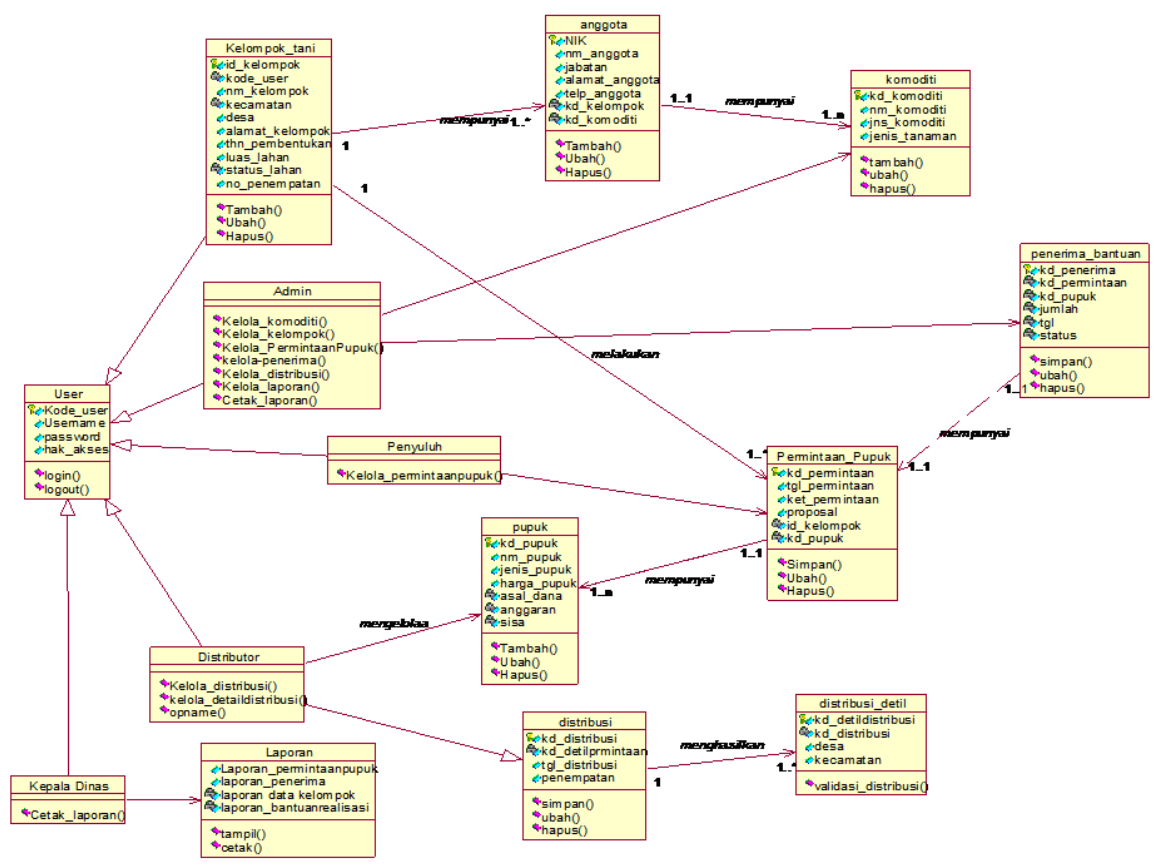

Gambar 4. Class Diagram Sistem Informasi Penyaluran Bantuan Pupuk Bersubsidi

\subsubsection{Entity Relationship Diagram(ERD)}

Entity Relationship Diagram merupakan model konstruksi yang menggunakan penyusunan data dan dibuat dalam sistem dengan bentuk abstrak. Diagram ini menekankan pada struktur-struktur dan relationship data [8]. Entity Relationship Diagram pada Sistem Informasi Penyaluran Bantuan Pupuk Bersubsidi dapat dilihat pada gambar 5. ERD digunakan untuk melakukan perancangan database secara konseptual sebelum akhirnya menjadi relasi table dalam sistem database.

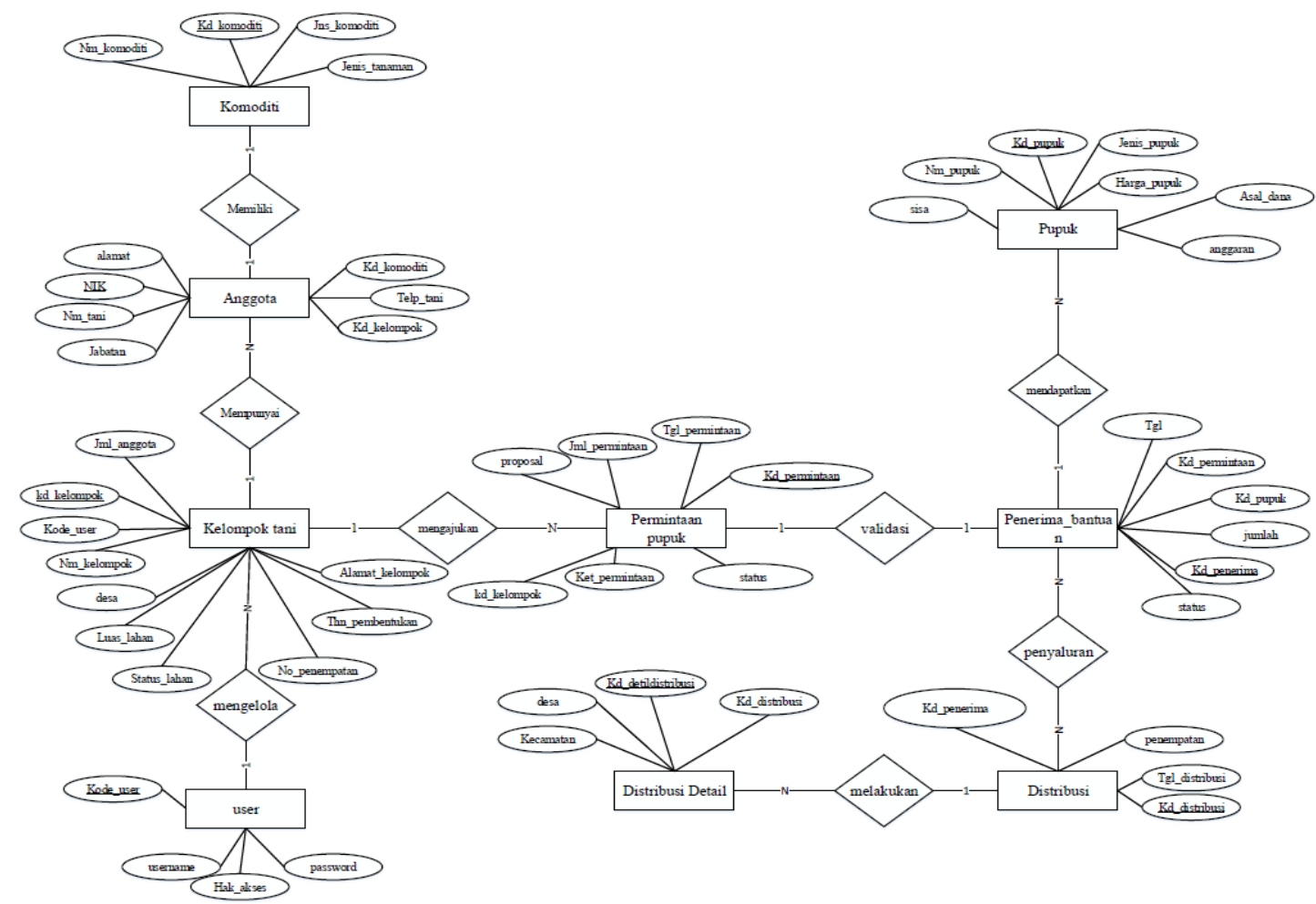

Gambar 5. Entity Relationship Diagram Sistem Informasi Penyaluran Bantuan Pupuk Bersubsidi 


\subsubsection{Relasi Tabel}

Hasil dari desain database melalui ERD dituangkan dalam Relasi Tabel. Relasi Tabel dari Sistem Informasi Penyaluran Bantuan Pupuk Bersubsidi dapat dilihat pada gambar 6. Relasi tabel menggambarkan keterkaitan antar tabel dalam satu database yang menandakan adanya integrasi data pada sistem yang dibuat.

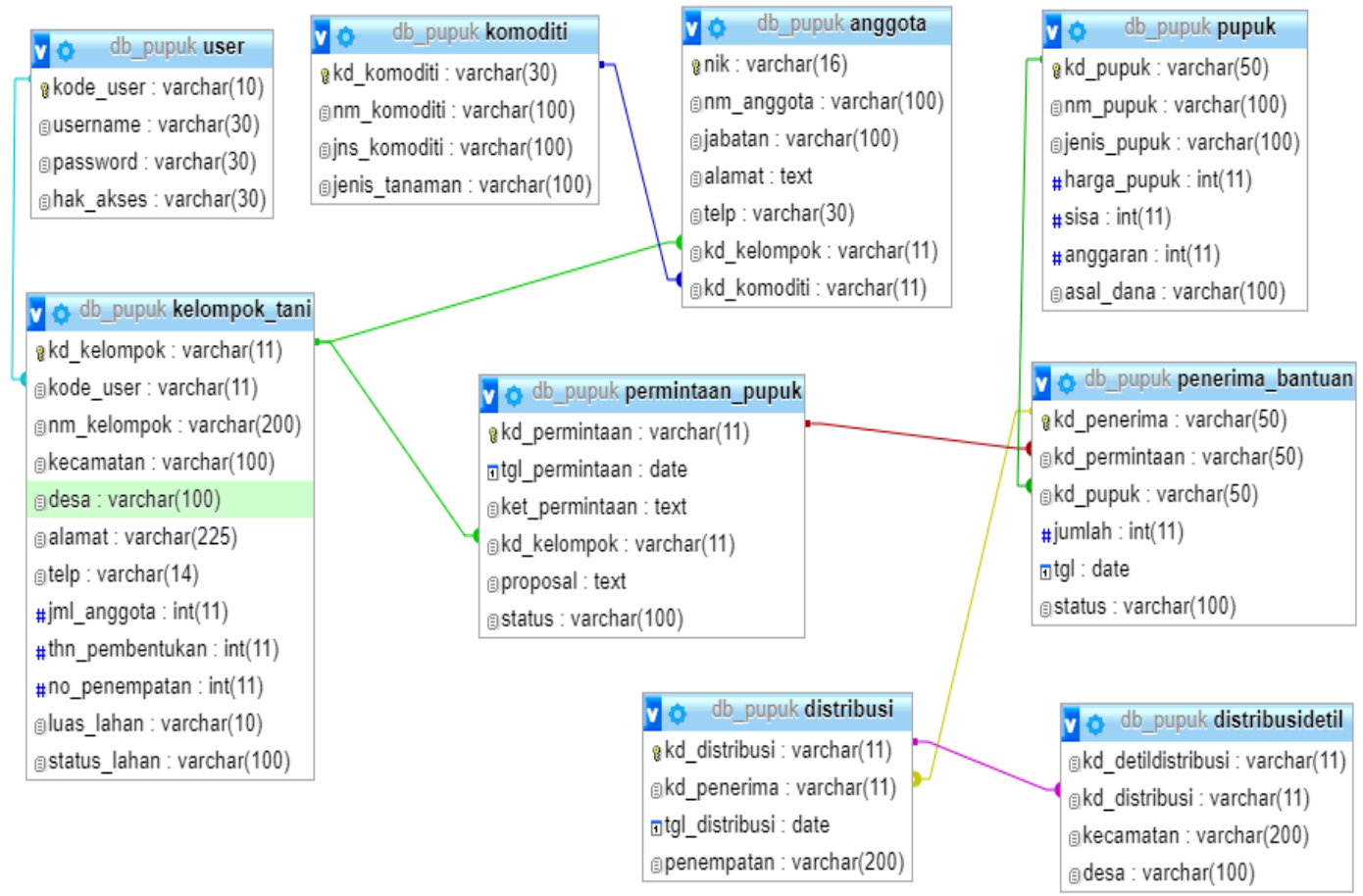

\section{Gambar 6. Relasi Tabel Sistem Informasi Penyaluran Bantuan Pupuk Bersubsidi}

\subsubsection{Implementasi}

a. Halaman utama Admin

Setelah login, Admin diarahkan sistem ke halaman utama milik admin yang memiliki menu Master Data yang berisi sub menu Pengolahan Data Komoditi dan Data Kelompok, menu Bantuan dan menu User. Pada halaman admin juga ditampilkan rekap dari data kelompok, data permintaan, data distribusi dan data user yang dapat ditampilkan dengan perintah klik. Tampilan Halaman Utama untuk Admin terdapat pada gambar 7 .

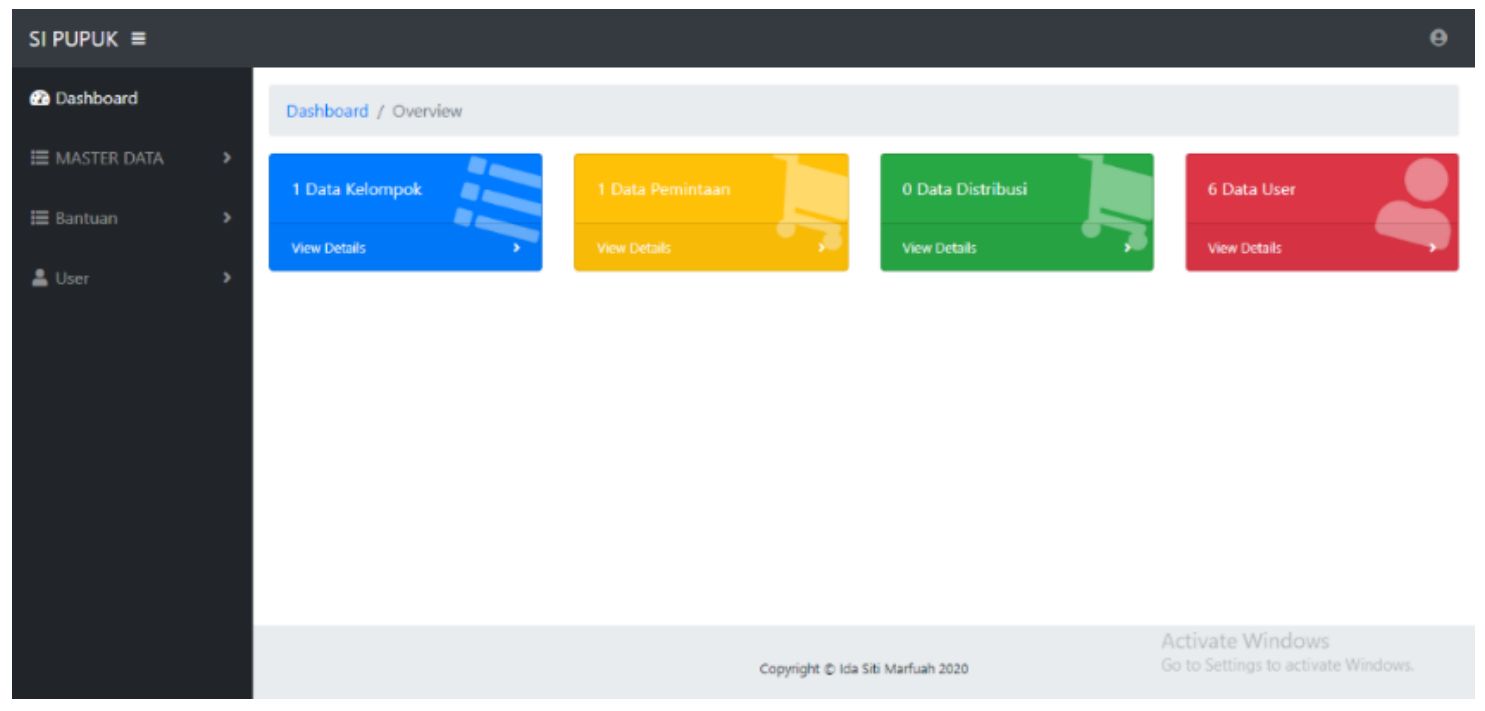

Gambar 7. Halaman Utama Admin 
b. Halaman Utama Penyuluh

Halaman utama bagian penyuluh ini merupakan tampilan utama yang muncul setelah Penyuluh masuk ke sistem dengan login. Pada halaman login ini memiliki menu Data Permintaan dan menu Permintaan Bantuan. Berikut merupakan tampilan pada halaman utama bagian penyuluh dapat dilihat pada gambar 8 .

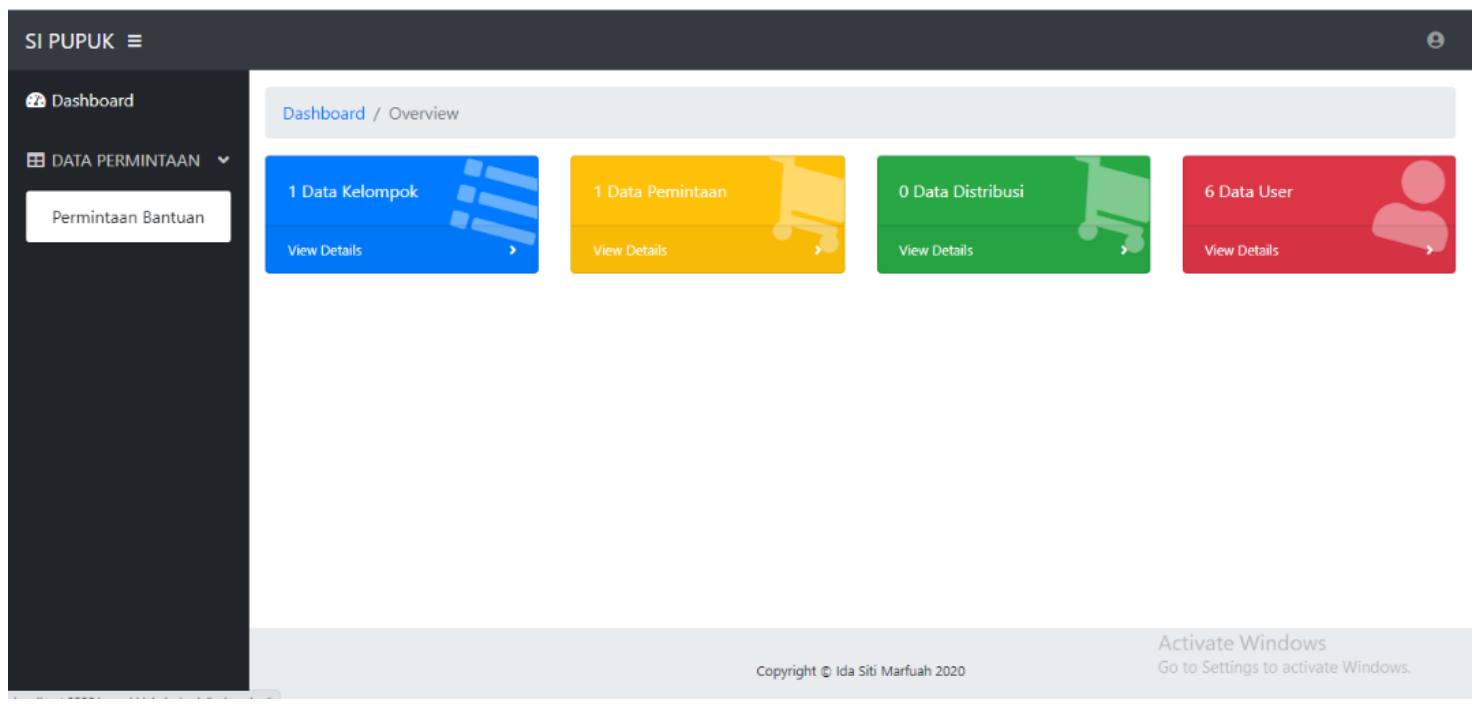

\section{Gambar 8. Halaman Utama Penyuluh}

c. Halaman Utama Distributor

Halaman utama bagian distributor ini merupakan tampilan utama yang muncul setelah distributor masuk ke sistem dengan login. Pada halaman distributor ini memiliki menu Master Data, menu Bantuan dan menu Pengiriman. Berikut merupakan tampilan dari halaman utama bagian distributor dapat dilihat pada gambar 9 .

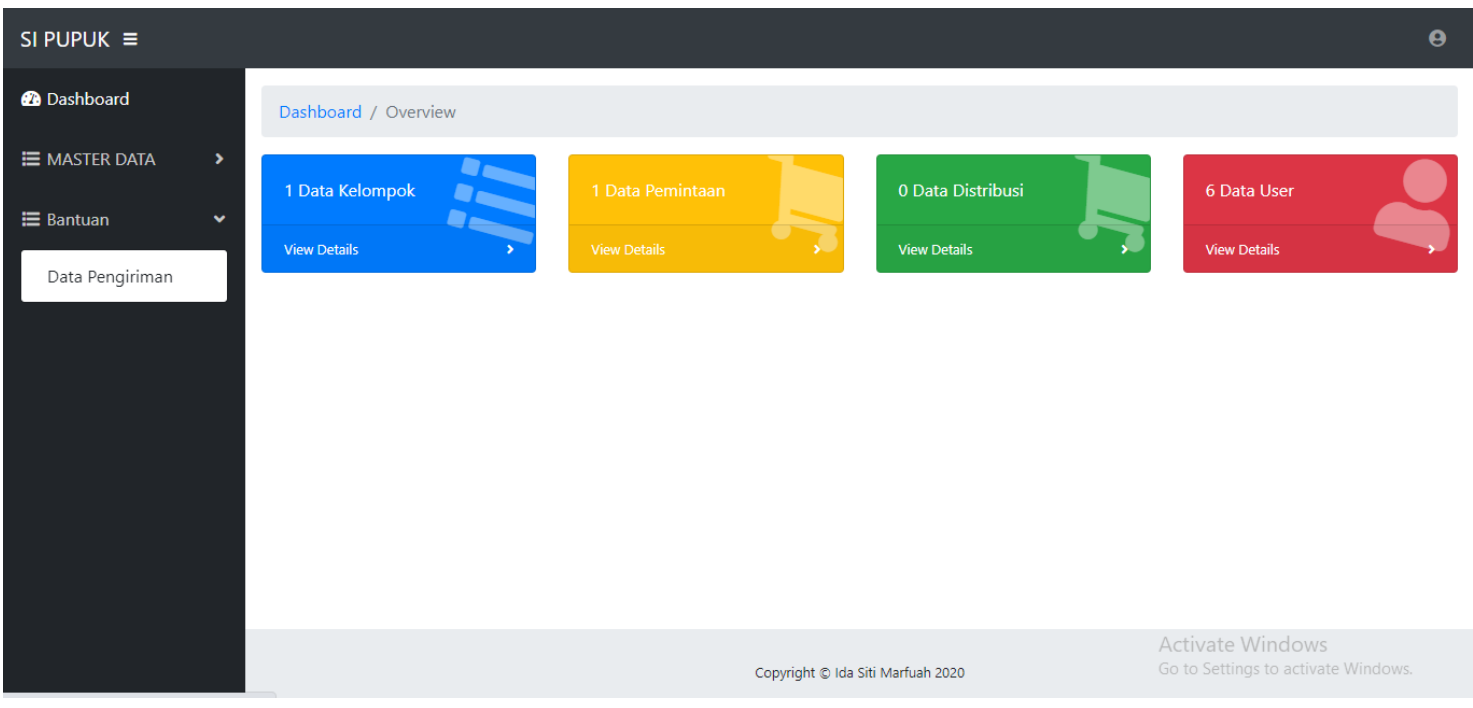

\section{Gambar 9. Halaman Utama Distributor}

d. Halaman Utama Kelompok Tani

Halaman utama bagian kelompok ini merupakan tampilan utama yang muncul setelah kelompok tani masuk ke sistem dengan login. Pada halaman kelompok tani ini terdapat menu Master data, menu Anggota dan menu Pengajuan. Berikut merupakan tampilan dari halaman utama bagian kelompok dapat dilihat pada gambar 10 . 


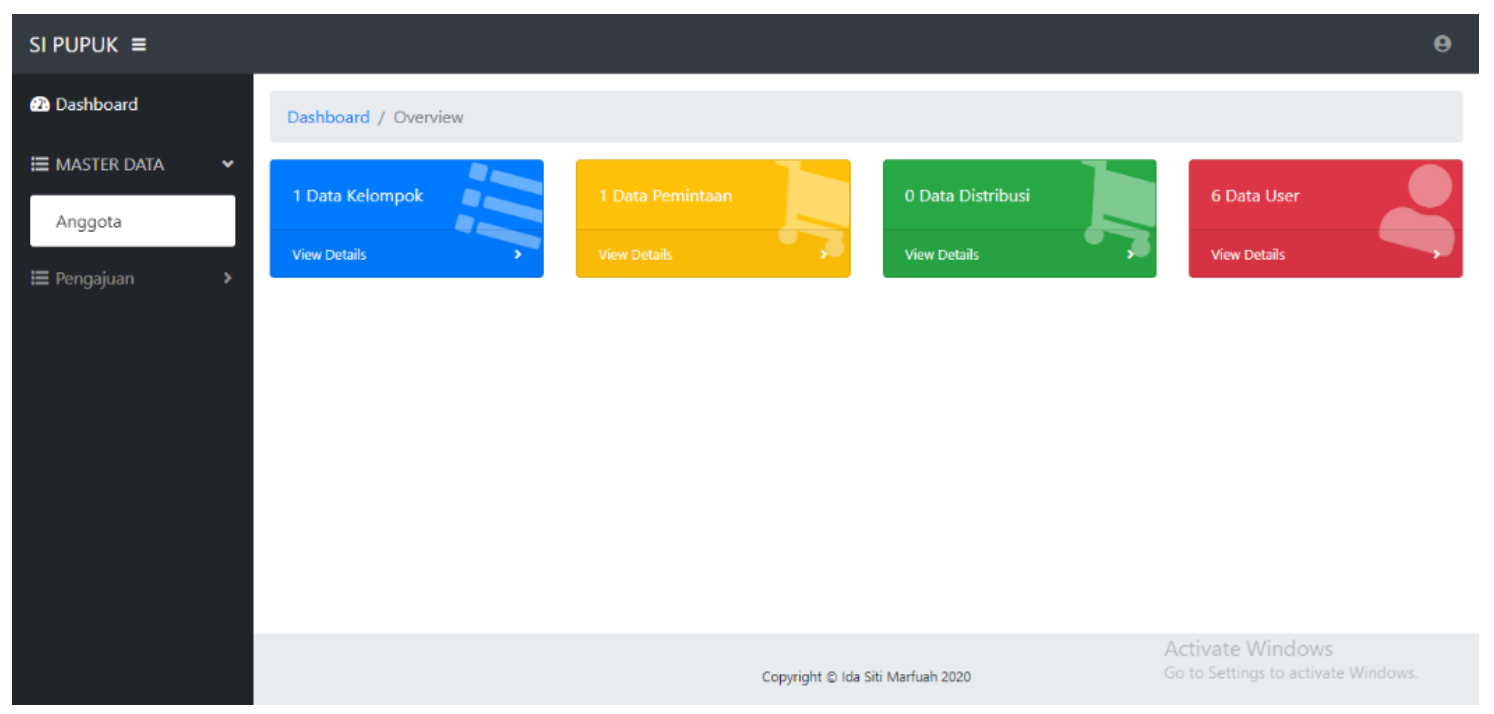

Gambar 10. Halaman Utama Kelompok Tani

e. Form Input Permintaan

Form Input permintaan digunakan untuk memasukkan data permintaan atau kebutuhan pupuk dari petani ke sistem, yang nantinya akan divalidasi oleh penyuluh dan diteruskan ke distributor. Tampilan Form Input Permintaan dapat dilihat pada gambar 11.

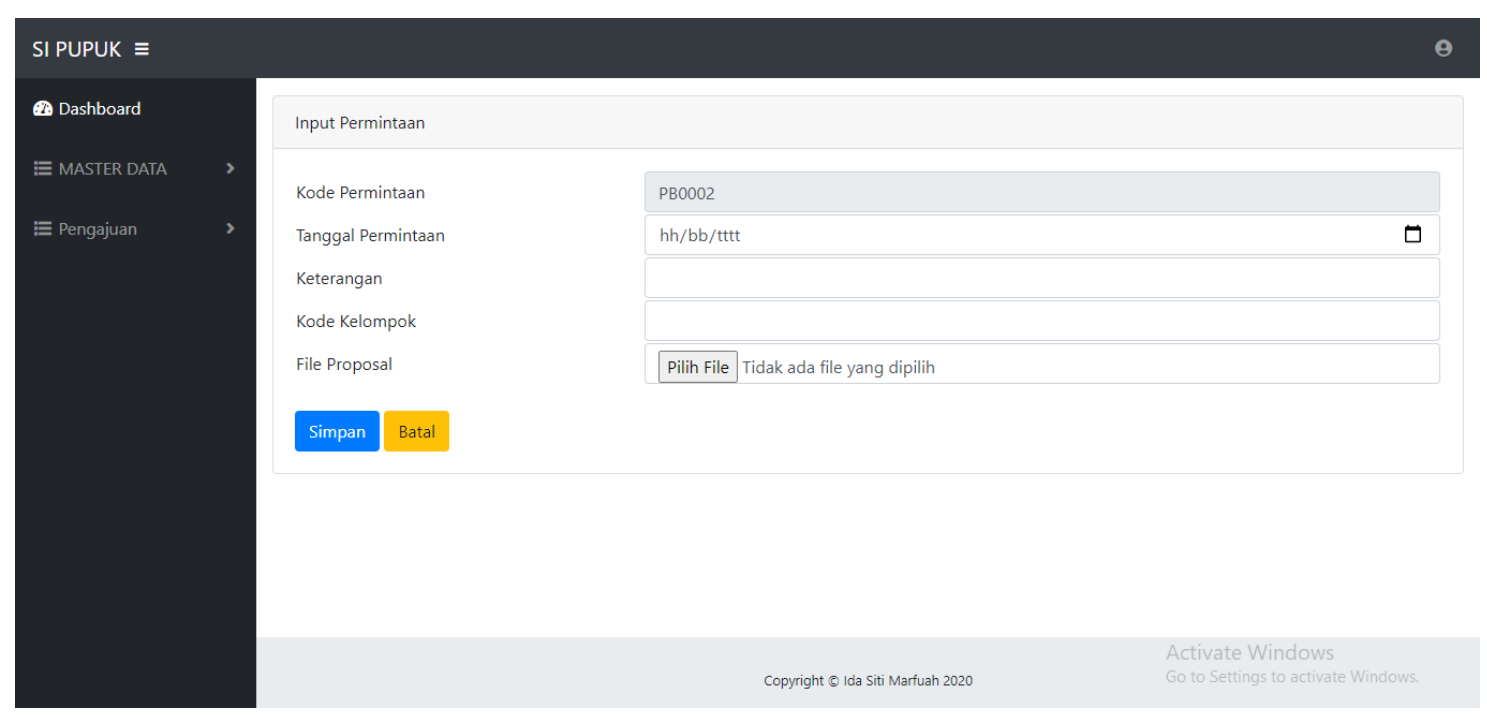

Gambar 11. Form Input Permintaan

\section{KESIMPULAN}

Berdasarkan hasil analisis dan hasil perancangan pada tiap tahap implementasi sistem, maka dapat disimpulkan tentang sistem ini sebagai berikut :

1) Sistem informasi penyaluran bantuan pupuk bersubsidi pada Dinas Pertanian dan Pangan Kabupaten Rembang Berbasis Web dibuat dengan menggunakan metode pengembangan sistem Waterfall dan menggunakan metode perancangan Object Oriented Design dengan perangkat perancangan UML yang terdiri dari Business Use Case, System Use Case, Class Diagram, Sequence Diagram, Activity Diagram dan Statechart Diagram. Sedangkan untuk perancangan database menggunakan Entity Relationship Diagram.

2) Sistem informasi penyaluran bantuan pupuk bersubsidi pada Dinas Pertanian dan Pangan Kabupaten Rembang Berbasis Web ini berhasil dibangun dengan Bahasa pemrograman PHP(Hypertext preprocessor) dan sistem manajemen database MySQL.

3) Sistem ini dibangun dengan tujuan untuk meningkatkan pengelolaan data permintaan pupuk bersubsidi dari petani melalui petugas penyuluh dan distributor. Data - data yang digunakan antara lain data 
pupuk, data kelompok tani, data komoditi, data permintaan pupuk dan data pengiriman pupuk. Kepala Dinas memiliki peran untuk mengawasi jalannya sistem melalui laporan - laporan yang diterima.

\section{DAFTAR PUSTAKA}

[1] BAPPEDA Kab. Rembang. (2018). Review RPIJM Bidang Cipta Karya Kabupaten Rembang Tahun 2018 2022, Rembang: Pemda Kabupaten Rembang.

[2] Ragiman, Makmun, and Setiawan, S., 2020. "Strategi Penyaluran Pupuk Bersubsidi di Indonesia," Jurnal Ilmiah M-Progress, vol. X, no. 1, pp. 69-89, Januari.

[3] Sari,M., (2017). "Sistem Pengolahan Data Kelompok TAni Kecamatan Sungai Tabuk Kabupaten Banjar," Technologia, vol. 8, no. 3, pp. 171-176, Juli - September.

[4] Sriwinarti, N.K.,and Faesal, A., (2016). "Sistem Informasi Distribusi Pupuk Bersubsidi Pada Kecamatan Gerung Lombok Barat," Jurnal Matrik, vol. XV, no. 1, pp. 1-5, 2016.

[5] Pressman, R.S.(2005). Software Engineering A Practitioner's Approach, Sixth Edition., New York: McGraw-Hill Companies, Inc.

[6] Jogiyanto. (2005). Analisis dan Desain Sistem Informasi : Pendekatan Terstruktur Teori dan Praktik Aplikasi Bisnis, Edisi III ed., Yogyakarta: CV Andy Offset.

[7] Kendall, E. Kenneth, and Kendall, Julie E. (2006). System Analysis And Design, 8th Edition., New Jersey: Prentice Hall.

[8] Ladjamudin,Al Bahra bin. (2006). Rekayasa Perangkat Lunak, Edisi Pertama ed., Yogyakarta: Graha Ilmu. 